\title{
Korelasi antara Immature Granulocytes dan Delta He sebagai Penanda Inflamasi pada Penderita dengan Lekositosis
}

\author{
Novina Aryanti ${ }^{1 *}$, Juli Soemarsono ${ }^{2}$ \\ Bagian Patologi Klinik, FK Universitas Wijaya Kusuma Surabaya ${ }^{1}$ \\ Departemen Patologi Klinik, FK Unair /RSUD Dr Soetomo Surabaya ${ }^{2}$ \\ *e-mail: novena.aryanti@gmail.com
}

\begin{abstract}
Abstrak
Immature Granulocytes dapat digunakan sebagai penanda inflamasi. Saat ini Delta He diduga dapat digunakan untuk penanda baru inflamasi. Tujuan penelitian ini ingin mengetahui korelasi antara Immature Granolocytes dan Delta He sebagai penanda inflamasi pada penderita dengan lekositosis. Pada penelitian ini digunakan sampel darah-EDTA dari 50 penderita lekositosis di RSUD Dr. Soetomo Surabaya mulai 1017 Desember 2011, yang diperiksa Delta He dan Immature granulocytes dengan Flowcytometri (Sysmex XE-2100). Hasil dianalisis secara statistik menggunakan Uji korelasi dari Pearson product moment. Hasil penelitian menunjukkan bahwa Mean Immature Granulocytes dan Delta He 50 penderita dengan lekositosis adalah $0.37 \times 10^{3} / \mu \mathrm{L}$ dan $3.03 \mathrm{pg}$. Uji Statistik berdasarkan Pearson test antara Immature Granulocytes dan Delta He menunjukkan korelasi $(r=0.26)$, dan nilai $p>0.05$ sehingga disimpulkan korelasi tersebut tidak bermakna. Inflamasi merangsang pelepasan sitokin yang akan meningkatkan kadar hepcidin, dengan akibat terjadi penurunan ferroportin pada duodenum dan makrofag sehingga suplai besi ke sel precursor eritropoetik berkurang dan menyebabkan penurunan sintesis hemoglobin (Ret He). Penderita dengan lekositosis belum tentu menderita sepsis, sehingga tidak terjadi peningkatan Immature Granulocytes pada semua penderita lekositosis. Sehingga dapat disimpukan bahwa Immature Granulocytes dan Delta He pada penderita dengan lekositosis memiliki korelasi yang kurang bermakna. Sehingga diperlukan penelitian lebih lanjut untuk menentukan apakah Delta He dapat digunakan sebagai penanda inflamasi.
\end{abstract}

Kata Kunci: Immature Granulocytes, Delta He, Lekositosis, Inflamasi, Flowcytometri.

\section{Correlation Between Immature Granulocytes and Delta He as Inflammation Marker in Patients With Lecocytosis}

\begin{abstract}
Immature Granulocytes are considered as an inflammation marker. Recently Delta He is suspected to be a novel marker of inflammation. The aim of this study is to know the correlation of Immature Granulocytes and Delta He as inflammation marker in patients with lecocytosis. This research used whole blood-EDTA samples from 50 lecocytosis patients in the Dr. Soetomo Hospital Surabaya from 10 until 17 December, 2011 were studied Immature granulocytes and Delta He were examined by Flowcytometry (Sysmex XE 2000i). Analysis of the results was performed by Pearson product moment. Mean result of Immature Granulocytes and Delta He from 50 patients with lecocytosis was $0.37 \times 10^{3} / \mu \mathrm{L}$ and $3.03 \mathrm{pg}$. According to Pearson analysis test there was a correlation between Immature Granulocytes and Delta $\mathrm{He}(r=0.26)$, but this was not significant ( $p>0.05$ ). Inflammation induced cytokine release and rise hepcidin, the result was decrement of ferroportin from duodenum and macrophage so the iron supply to erythropoetic precursor decrease, and the hemoglobin synthesis (Ret He) decrease. The rise of Immature Granulocytes were not happened in all lecocytosis patients, it were not certain suffered sepsis. There was no significant correlation between Immature Granulocytes and Delta He in patients with lecocytosis. A further research with more samples to determine that Delta He can be used as an inflammation marker is needed
\end{abstract}

Keywords: Immature granulocytes, Delta He, Lecocytosis, inflammation, Flowcytometry 


\section{LATAR BELAKANG}

Inflamasi adalah respon biologis yang kompleks dari jaringan vaskuler terhadap stimuli yang membahayakan tubuh, seperti patogen, perusak sel atau atau iritan. Inflamasi merupakan suatu usaha protektif oleh organisme guna melenyapkan stimuli yang membahayakan dan merupakan usaha awal dari proses penyembuhan.

Inflamasi diklasifikasikan dalam inflamasi akut dan inflamasi kronik. Inflamasi akut merupakan respon awal tubuh terhadap stimuli berbahaya dan ditandai dengan terjadinya pergerakan plasma dan lekosit (terutama granulosit) dari dalam darah ke dalam jaringan yang mengalami jejas. Inflamasi yang berkepanjangan dinamakan inflamasi kronis yang ditandai dengan meningkatnya jumlah berbagai macam tipe sel didalam jaringan yang mengalami jejas dan terjadinya destruksi simultan tersebut serta diikuti dengan proses penyembuhan jaringan dari proses inflamasi.

Sel-sel yang berperan dalam inflamasi disebut sel inflamasi atau komponen seluler inflamasi, beberapa diantaranya berada dalam jaringan normal antara lain sel mast dan makrofag, sedang yang lain berada dalam sirkulasi (limfosit, Netrofil, Eosinofil,Basofil, dan trombosit) dan baru akan memasuki jaringan apabila terdapat respon inflamasi $(1,2)$.

Pehitungan jumlah lekosit, termasuk neutrofil, penting pada pasien yang memiliki penyakit infeksi, karena berperan penting pada peradangan akut dalam melawan infeksi bakteri. Beberapa penelitian telah membahas kegunaan dari jumlah total lekosit, jumlah neutrofil, dan jumlah band / stab dalam memprediksi penyakit infeksi. Pemeriksaan penanda shift to the left dari granulopoiesis, telah diketahui sulit untuk mengukur secara akurat atau tepat. Pengukuran granulosit muda bisa menjadi parameter yang bermanfaat untuk mendeteksi dini infeksi/peradangan atau sepsis.

Immature granulocytes dan selisih kadar hemoglobin pada eritrosit matur dan retikulosit (delta $\mathrm{He}$ ) pada hematology analyzer dapat digunakan untuk mendeteksi inflamasi. Pada inflamasi merangsang pelepasan sitokin yang akan meningkatkan kadar hepcidin, dengan akibat terjadi penurunan ferroportin pada duodenum dan makrofag sehingga suplai besi ke sel precursor eritropoetik berkurang yang akan menyebabkan penurunan sintesis hemoglobin (3).

Oleh sebab itu maka tujuan dari penelitian ini adalah ingin mengetahui adakah hubungan atau korelasi antara Immature granulocytes dan delta He pada penderita lekositosis sehingga dapat diketahui apakah delta He dapat digunakan sebagai penanda inflamasi.

\section{BAHAN DAN METODE}

Penelitian ini merupakan studi cross sectional analitik, kriteria inklusi penelitian adalah penderita dengan lekositosis laki-laki ataupun perempuan dari 51 penderita lekositosis di RSUD Dr Soetomo Surabaya mulai 10-17 Desember 2011dan kriteria eksklusi adalah penderita dengan keganasan. Sampel darah diambil dari vena, untuk pemeriksaan darah lengkap dan ditampung dengan antikoagulan EDTA, yang diukur dengan menggunakan alat Sysmex- XE 2100 dengan prinsip pemeriksaan spektrofotometri. Lekositosis adalah kadar lekosit lebih dari 10.300 dengan satuan per $\mu \mathrm{L}$. Immature Granulocytes (Granulosit imatur) adalah netrofil imatur (promyelosit, metamyelosit, myelosit, netrofil stab ) dengan satuan per $\mu \mathrm{L}$. Delta He adalah selisih antara $\mathrm{MCH}$ dan Ret He dengan satuan pg. $\mathrm{MCH}$ adalah kandungan Hemoglobin dalam eritrosit dengan satuan pg. Sedangkan Ret He adalah kandungan Hemoglobin dalam retikulosit dengan satuan pg. Uji statistik One-Sample Kolmogorov-Smirnov Test menggambarkan distribusi sampel. Untuk analisis korelasi menggunakan uji korelasi Pearson.

\section{HASIL}

Pada penelitian ini didapatkan 51 sampel penderita dengan lekositosis. Dengan uji One sample Kolmogorov-Smirnov, didapatkan hasil sampel penelitian terdistribusi normal sehingga dapat dianalisis menggunakan uji Pearson (tabel 1) Mean dari IG 0.3725 dan mean Delta He adalah 3.0373. Standar Deviasi IG adalah 0.84951 dan Delta He adalah 2.34358 
ISSN 1978-2071 (Print); ISSN 2580-5967 (Online) Jurnal IImiah Kedokteran Wijaya Kusuma 5(2) : 1-5

Tabel 1. Uji One sample Kolmogorov-Smirnov

One-Sample Kolmogorov-Smirnov Test

\begin{tabular}{|c|c|c|c|}
\hline & & IG & $\mathrm{dHE}$ \\
\hline $\mathbf{N}$ & & 51 & 51 \\
\hline \multirow{3}{*}{ Normal Parameters ${ }^{\mathrm{a}, \mathrm{b}}$} & Mean & .3725 & 3.0373 \\
\hline & Std. Deviation & .84951 & 2.34358 \\
\hline & Absolute & .360 & .131 \\
\hline \multirow[t]{2}{*}{ Most Extreme Differences } & Positive & .360 & .131 \\
\hline & Negative & -.343 & -.105 \\
\hline Kolmogorov-Smirnov Z & & 2.571 & .933 \\
\hline Asymp. Sig. (2-tailed) & & .000 & .349 \\
\hline
\end{tabular}

a. Test distribution is Normal.

b. Calculated from data.

Tabel 2. Uji Korelasi (Pearson)

Correlations

\begin{tabular}{|ll|r|r|}
\hline & & \multicolumn{1}{|c|}{ IG } & \multicolumn{1}{|c|}{ dHE } \\
\hline \multirow{4}{*}{ IG } & Pearson Correlation & 1 & .026 \\
& Sig. (2-tailed) & & .858 \\
& $\mathrm{~N}$ & 51 & 51 \\
& Pearson Correlation & .026 & 1 \\
dHE & Sig. (2-tailed) & .858 & \\
& $\mathrm{~N}$ & 51 & 51 \\
\hline
\end{tabular}

Uji statistik berdasarkan Pearson test antara Immature Granulocytes dan Delta He dengan korelasi $(r=0,26)$, yang berarti semakin mendekati 1 maka korelasi semakin kuat, dan semakin mendekati nol, korelasi semakin lemah. Signifikansi korelasi $(r=0,26)$ antara IG dan Delta He adalah 0,858 artinya nilai $p$ hasil analisis lebih besar dari $\alpha(0.05)$ sehingga disimpulkan korelasi tersebut tidak bermakna.

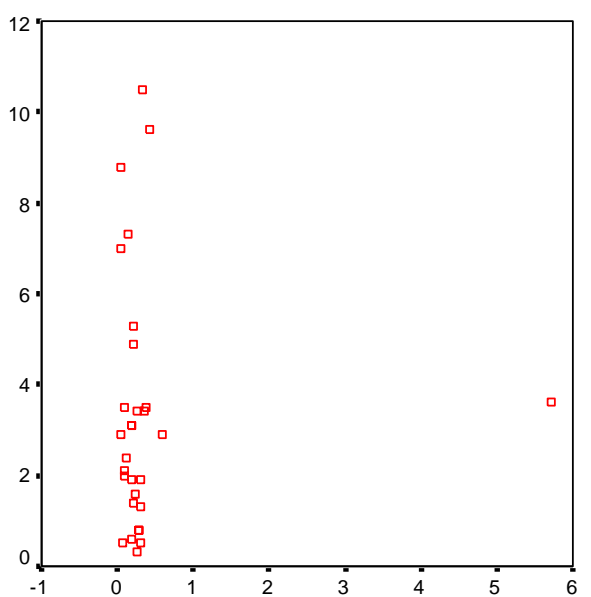

IG

Gambar 1. Diagram Scatter Plot antara Immature Granulocytes dan Delta He

Gambar 1 menunjukkan bahwa korelasi antara Immature Granulocytes dan Delta He positif lemah dan kurang bermakna.

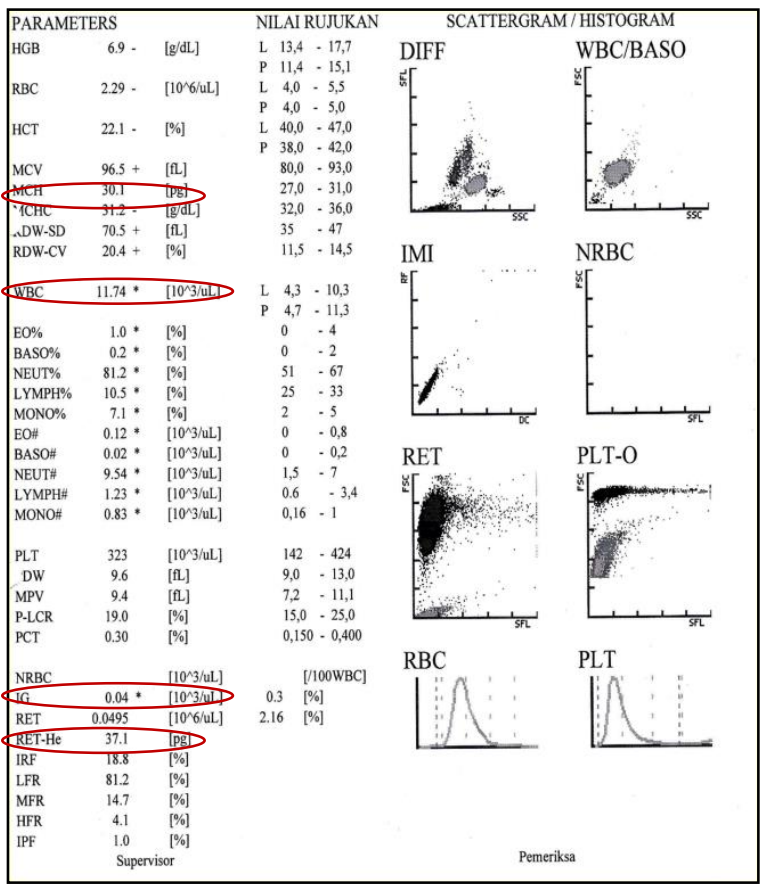

Gambar 2. Hemogram. Nilai WBC, Delta He (Ret $\mathrm{He}-\mathrm{MCH}$ ) dan IG 


\section{PEMBAHASAN}

Immature granulocytes meliputi neutrofil batang, metamielosit, mielosit, dan promielosit. Neutrofil matur adalah neutrofil segmen. Inflamasi dan infeksi akan menyebabkan pelepasan neutrofil ke dalam aliran darah, sehingga akan meningkatkan jumlah sel darah putih. Pada keadaan infeksi bakteri akut dijumpai pergeseran ke kiri dari neutrofil, yakni dengan banyak dijumpai bentuk batang, dan bentuk neutrofil imatur lainnya. Neutrofil imatur umumnya ditemukan pada infeksi dan sepsis.

Delta He adalah selisih kadar Hemoglobin eritrosit muda (retikulosit) dan kadar Hemoglobin eritrosit matur, yang saat ini diduga dapat digunakan sebagai penanda inflamasi. Inflamasi akan merangsang peningkatan ekspresi hepcidin oleh IL-6, pengaruh hepcidin ini akan berpengaruh pada metabolisme besi (Gambar 3) yaitu menghambat release besi dari makrofag dan menurunkan penyerapan besi dari usus sehingga ketersediaan besi untuk proses eritropoesis menjadi terbatas (penurunan besi untuk sintesis hemoglobin, kadar hemoglobin retikulosit (Ret $\mathrm{He}$ ) akan menurun) $(2,4,5)$.

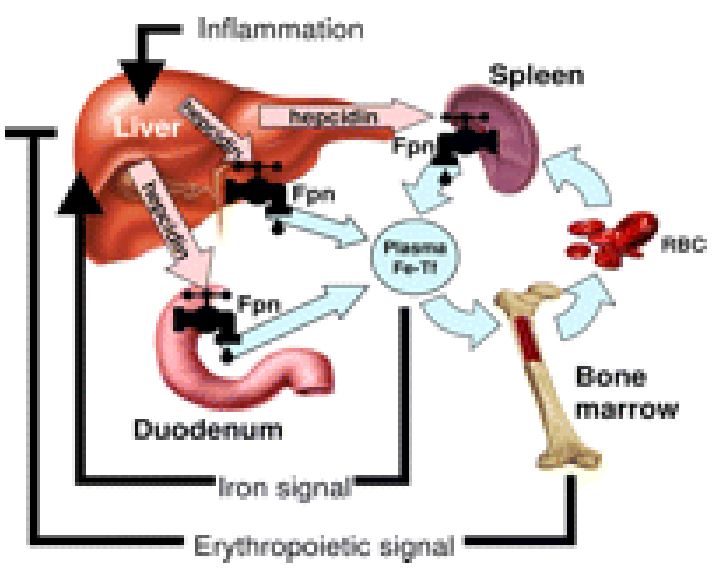

Gambar 3. Pengaturan Hepcidin pada metabolisme besi (6).

Mekanisme pengaturan produksi hepcidin antara lain:

a. Pengendalian besi akan meningkat dengan pengaruh saturasi transferin yang tinggi dan menurun dengan kadar besi plasma yang rendah serta adanya supresi akibat ekspresi hepcidin.

b. Pengendalian eritropoiesis c. Inflamasi, tidak tergantung pada besi dan eritropoiesis, tetapi dirangsang oleh IL-6 dan sitokin.

Pada keadaan Lekositosis, kadar Immature Granulocytes akan meningkat, sedangkan kadar Delta He akan menurun. Dengan uji statistik berdasarkan Pearson test antara Immature Granulocytes dan Delta $\mathrm{He}$ menunjukkan korelasi kurang signifikan ( $p$ > $0,05)$, hal ini di karenakan penderita dengan lekositosis tidak seluruhnya disebabkan sepsis dimana Immature Granulocytes merupakan marker untuk sepsis(6). Lekositosis dapat juga disebabkan faktor non sepsis sehingga kadar Immature Granulocytes dan Delta He tidak dapat berkorelasi dengan baik (7).

\section{KESIMPULAN}

Immature Granulocytes dan Delta $\mathrm{He}$ pada penderita dengan lekositosis memiliki korelasi yang kurang bermakna. Sehingga diperlukan penelitian lebih lanjut untuk menentukan apakah Delta He dapat digunakan sebagai penanda inflamasi dengan jumlah sampel yang lebih banyak dan menggunakan sampel penderita dengan diagnosis sepsis dan non sepsis.

\section{DAFTAR PUSTAKA}

1. Ma'at, S., 2012. Inflamasi. Airlangga University Press.; pp: 1-25

2. Welmann A, Lun A, Lun S., 2010. Leucocyte, neutrophil, immature granulocyte counts and Interleukin-6 are superior to procalcitonin, C-reactive protein and deltaHe for detection of mild inflamation: data from marathon runners producing mild systemic inflamation viable immediately after the run. J lab Med.;34(1):53-59.

3. Rossi, E., 2005. Hepcidin-the Iron regulatory Hormone. Clin Biochem Rev.; 26. pp: 47-49

4. Agustriadi O, Suega K., 2006. Hepcidin pada Anemia of Chronic Disease. Tinjauan pustaka. Bag IImu Penyakit dalam FK UnudDenpasar.; 7 (2) pp: 141-8

5. Chung Hyun Nahm, Jong Weon Choi., 2008. Delta Neutrophil Index in Automated Immature Granulocyte Counts for Assessing Disease Severity of Patients with Sepsis.; pp 1-6

6. Ganz T, Nemeth E, Goodnough L., 2012. Detection, evaluation, and management of 
ISSN 1978-2071 (Print); ISSN 2580-5967 (Online) Jurnal IImiah Kedokteran Wijaya Kusuma 5(2) : 1-5

iron-restricted erythropoiesis. Review article. Blood journal hematology library org.; $2-9$

7. Hiew TM, Tan AM, Cheng HK. 1992, Clinical Features and Haematological Indices of Bacterial Infections in Young Infants. Singapore med J; 33:125-1

8. Byung Hoon Park, Young Ae Kang, 2011. Delta neutrophil index as an early marker of disease severity in critically ill patients with sepsis. BMC Inf. Diseases.; pp 1-9 